Rev Chil Salud Pública 2012; Vol 16 (2): 94-95

\section{Editorial invitada}

\section{Derechos explícitos, deberes vinculantes}

\section{GUARANTEED RIGHTS AND RELATED RESPONSIBILITIES}

Los derechos comienzan a ser motivo de reflexión con el nacimiento de las democracias modernas y el reconocimiento del individuo es liberado del yugo de la soberanía autoritaria que decreta el orden del mundo, y reconocido en su libertad para forjar su destino en libertad mediante el ejercicio de ciertas permisiones o derechos. El que la libertad se predique de todo ser humano en tanto individuo capaz de ejercerla, significa que se reconoce un derecho universal a ser libre de coartaciones, reconociéndosele que "el verdadero derecho del hombre...es la posibilidad adquirir derechos (Fichte) o, más actual y breve, de tener "el derecho de tener derechos" (Arendt).

La libertad es un atributo primario que no compromete a los demás salvo en el "no-derecho" de limitar injustificadamente su ejercicio. Un derecho, en cambio, es socialmente reconocido como la potestad de reclamar algo frente a alguien que tiene la obligación correlativa de dar cumplimiento al reclamo. El ejercicio de un derecho es opcional, que si no lo fuese, sería un deber. El derecho a voto, por ejemplo, será un deber si no es optativo.

La libertad de hacer uso de la igualdad de oportunidades, es hija de culturas liberales que dejan en manos de cada uno la elaboración de su proyecto de vida. En sociedades desiguales, el derecho individual a forjarse una existencia no puede ser igualmente ejercido por todos debido a enormes disparidades de empoderamiento. Por ende, si el ser humano es universalmente detentor del derecho básico de conquistar derechos sociales y políticos, será una obligación también universal empoderarlo para ejercer ese derecho generador de derechos, poniendo a su disposición los instrumentos necesarios para reclamar el cumplimiento de esos derechos. ¿Quién si no el Estado asumirá la obligación de empoderar a sus ciudadanos otorgando educación, atención médica y sustento mínimo? En un país como Chile, maculado por un índice Gini de 0.54, el Estado no puede esgrimir argumentos políticos o económicos para eximirse de la obligación de empoderar -cuidar, educar- a todos sus ciudadanos.

La Ley de Derechos y Deberes no se hace cargo de que hay ciertas obligaciones que son primarias y no requieren ser invocadas por derechos porque son bienes y servicios a otorgar incondicionalmente y en independencia de que el paciente quiera o pueda requerirlos ("derecho a calidad de la atención de salud"). No es que el paciente tenga derecho a un trato digno y a una atención técnicamente eficiente, sino son estas obligaciones que le corresponde recibir, las solicite o no. A nivel general, la Constitución concede poco, sí proclama un derecho a protección de la salud, que deja la cobertura de atención médica al arbitrio de circunstancias, en vez de asumir el deber de cobertura médica de un modo pasible de ser controlado, evaluado y reclamado. Ya tenemos la experiencia de las GES/Auge que proclaman atención médica "universal e integral", para luego elaborar programas de exclusiones, limitaciones y postergaciones. En toda la Ley nada se dice acerca de garantizar atención médica a quien la necesite, pero sí se concede el menudo derecho del "libre acceso" a la "información que contenga los precios de las prestaciones" en instituciones "públicas y privadas". 
Cada vez que la sociedad reconoce un derecho, está estableciendo una barrera de exclusión para quienes no tienen ese derecho, que si fuese universal e incondicionado, no necesitaría el refuerzo de una ley. En efecto, la Ley es cuidadosa en conceder derechos a los pacientes mediante el recurso de negarlos a otros, que son los mentalmente incompetentes, los legalmente menores de edad, los enfermos mentales, los pacientes "terminales". O sea, el instrumento legal es una herramienta de exclusión que transfiere la autonomía de decisiones, a "juicio de su médico tratante", a los Comités de Ética, a la Comisión de Enfermedades Mentales, a la Corte de Apelaciones. Con el agravante que la cesura de exclusión es vaga, quedando, según el caso, a criterio del médico, 0 en manos del paciente que decide a condición que no "acelere artificialmente el proceso de [su] muerte". El paciente "terminal" tiene "derecho a los cuidados paliativos", o sea, facultativamente puede rechazarlos (¿acelerando con ello el proceso de muerte?), porque no es obligación del "prestador" proporcionárselos a menos que los solicite. Excluye la frase "Ni siquiera", al parecer, es obligatorio disponer del costoso arsenal de la medicina paliativa.

En casos calificados, el médico "deberá solicitar la opinión del comité de ética", cuyo "pronunciamiento tendrá solo el carácter de recomendación". Hay un deber de consultar pero la facultad de no acatar. ¿Qué ocurre con el derecho del paciente a ejercer autonomía en este vaivén de instancias que asumen decisiones?

La ley es notoriamente negligente en su referencia a "menores de edad", no contemplando grados de madurez para tomar decisiones o la utilización del "asentimiento". El tema queda despachado al proclamar que en la "atención a menores de edad, el comité [de ética consultado] deberá tener en cuenta especialmente el interés superior de estos últimos". ¿Acaso en adultos queda el comité eximido de este requerimiento? ¿Y quién ilumina al comité para reconocer esto intereses superiores?

Hay mucho más. La interpretación mañosa y fuera de contexto es intencionada, para ilustrar que un texto ambiguo podrá también en la práctica ser utilizado en forma arbitraria.

Una ley basada en errores conceptuales, que confunde derechos con obligaciones, concede derechos obvios y genera áreas de exclusión arbitrariamente delimitadas, es una ley que no otorga sino protección deficiente al paciente, lo cual genera un desamparo mucho mayor que la falta de una ley, porque los incumplimientos y los desacatos se esconden en los pliegues y recovecos de las imprecisiones del texto. 